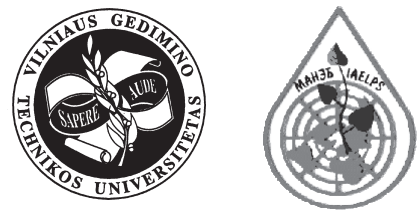

\title{
EXPERIMENTAL INVESTIGATION OF THERMAL MODIFICATION INFLUENCE ON SORPTION QUALITIES OF BIOSORBENTS
}

\author{
Pranas Baltrẻnas, Vaidotas Vaišis \\ Dept of Environmental Protection, Vilnius Gediminas Technical University, \\ Sauletekio al. 11, LT-10223 Vilnius-40,Lithuania.E-mail: aak@vtu.lt.
}

Received 29 Jun 2004; accepted 16 Dec 2004

\begin{abstract}
When collecting oil products from a water surface water soaking is unavoidable. It makes a sorbent sink into water and reduces its capacity to take oil products. Previous experiments have revealed [15] that a biosorbent made of moss growing in Lithuania absorb oil products efficiently from a water surface but water soaking is high (14 g of water / $\mathrm{g}$ of a sorbent). To reduce water soaking a biosorbent should be impregnated or modified in another way. Impregnation results in occurrence of certain substances in a sorbent that increase pollution, if the sorbent is left in nature. One of the most perspective ways of modification without extra chemical substances is thermal modification. During heating chemical changes (dissociation of $-\mathrm{COOH}$ and $-\mathrm{OH}$ free radicals) occur in a biosorbent, which have an influence on the combining of water molecules. A reduced number of these free radicals results in a reduced amount of soaked water. A biosorbent made of moss is very flammable, so definition of a sufficient and safe heating temperature and heating time is very important.
\end{abstract}

Keywords: oil spill, sorbents, thermal modification, optimal heating temperature.

\section{Introduction}

With expansion of the oil business, petroleum exploration, construction of new oil terminals, the level of environmental pollution risk is inevitably increasing. The oil spill during accidents causes the greatest damage to the environment. Oil and its products, having got into water and soil, may get localized and form films or be dispersed, forming oil and water emulsions [1-3].

When oil products get into the environment, first of all their localization is performed with the help of sorbents. In most cases priority is given to synthetic sorbents, their sorption qualities are better and they have potential for repeated use, if compared with natural sorbents $[4,5]$. However, waste synthetic sorbents cause undesirable problems [6, 7].

A peat-moss is an archetypal plant of swamps and swampy areas.

Very spongy cells of the plant with big intercells manage to consume a big quantity of water. Having no root and being unable to take mineral substances from the soil, a peat-moss takes everything from water.

It has been evaluated that the hygroscopic property of organic substances decreases by thermal treatment
[8]. Mild pyrolysis results in a significant increase in the hydrophobic property of lignocellosic materials.

So it is interesting to find out wether mild pyrolysis affects in the same way as a biosorbent produced from peat-moss. It is evaluated [8] that the best temperature for mild pyrolysis is about $350{ }^{\circ} \mathrm{C}$. So the aim of the work is to find out an optimal temperature of thermal modification and to define the influence of chemical structure changes on sorption qualities of a biosorbent.

\section{Investigation methods}

Experimental investigation was carried out at Mikkeli Polytechnical Laboratory (Finland) in August 2003. An IR spectrometer ATI Matson Genesis Series FTIR was used in the course of work.

Sorbent heating

$120 \mathrm{~g}$ of a ground and sieved biosorbent is dried at a room temperature. Then the sorbent is heated in a thermostatic oven until a steady mass is reached.

After preparatory work is done, the sorbent is put on special heating saucers and placed into a thermostatic oven. The temperature is gradually raised by $3{ }^{\circ} \mathrm{C}$ per 
minute till it reaches $150,200,225,250,300{ }^{\circ} \mathrm{C}$. Heating duration is $60 \mathrm{~min}$.

After each heating chemical changes occurring in the biosorbent structure are estimated with the help of IR spectrometer.

At the same time water and oil product (petrol and diesel) soaking capacity of the biosorbent is examined.

After an optimal heating temperature is defined, an experiment on the heating time is performed. At a certain temperature (an optimal one) the sorbent is heated for $10,30,60,120,180 \mathrm{~min}$.

After each heating chemical changes and water and oil product (petrol and diesel) absorption capacity of the biosorbent are examined.

\section{An experiment on water absorption}

A water absorption experiment is to verify the hydrophobic properties of a sorbent. The lower amount of water is absorbed by a sorbent, the better is its potential with regard to collection of oil products from a water surface $[9,10]$.

An experimental vessel is filled with water. It is filled with approximately 11 of water which reaches a depth of about $65 \mathrm{~mm}$ in the experimental vessel. As the test sorbent is bulk, a percolator is used for its collection from the water surface $[3,11,12]$.

The sorbent with a percolator is immersed into the experimental vessel filled with water and after a certain period of time water absorption is observed. The results of the experiment are given in a graph reflecting water absorption with regard to time ( $\mathrm{g}$ of water $/ \mathrm{g}$ of a sorbent).

An experiment on oil product absorption from a water surface

When collecting oil products from a water surface, a sorbent may absorb water and sink. Thus it is important to evaluate the efficiency of absorption from a wa-

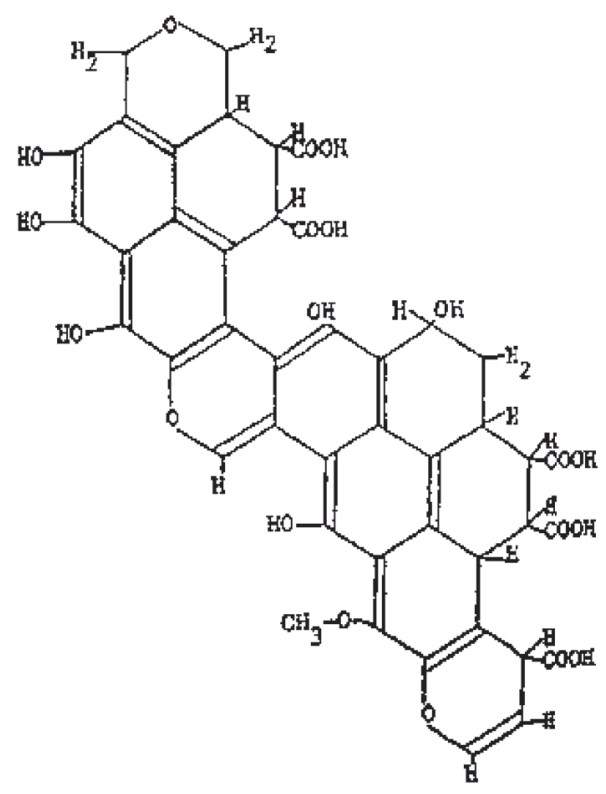

Fig 1. Chemical structure of peat-moss ter surface. Absorption of diesel fuel from a water surface is analysed. About 11 of water is poured into an experimental vessel which reaches a depth of about $65 \mathrm{~mm}$ in the experimental vessel. As the test sorbent is bulk, a percolator is used for its collection from the water surface. An oil product is spilled on the water surface. The thickness of the spilled layer is about $5 \mathrm{~mm}[3,11$, 12].

The sorbent with a percolator is immersed into the experimental vessel filled with water and oil product absorption is observed. The results of the experiment are given in a graph reflecting oil product absorption with regard to time ( $g$ of oil / $g$ of a sorbent).

\section{Investigation results}

Several chemical reactions of peat-moss, oil products and water being absorbed are possible $[8,13]$ :

1. kation exchange with $\mathrm{H}$ ions in $-\mathrm{COOH}$ between phenol hydroxides and heterocyclic groups;

2. exchange of metal kations;

3. occurrence of hydroxide links between polyvalent kations and hydroxide, lignin, cellulose;

4. occurrence of anion - kation links with ionogenic groups.

These reactions depend on the type of moss and its impurities. Heating of a biosorbent may free some functional groups which may result in impact on chemical reactions [14]. Fig 1 illustrates the chemical structure of peat-moss [13].

After heating a biosorbent, decrease in the sorbent mass due to loss of humidity was noticed. Sorbent mass losses at heating temperatures of $200,225,250,300{ }^{\circ} \mathrm{C}$ (heating time $60 \mathrm{~min}$ ) are given in Fig 2.

At $250{ }^{\circ} \mathrm{C}-300^{\circ} \mathrm{C}$ charring of the biosorbent was noticed. Thus, heating of the sorbent at $225^{\circ} \mathrm{C}$ (heating duration 120 and $180 \mathrm{~min}$ ) and $250^{\circ} \mathrm{C}$ (heating duration 10,30 and $60 \mathrm{~min}$ ) was given a deeper analysis.

Loss of the sorbent mass at a heating temperature of 225 and $250{ }^{\circ} \mathrm{C}$ with a different heating duration is illustrated in Fig 3.

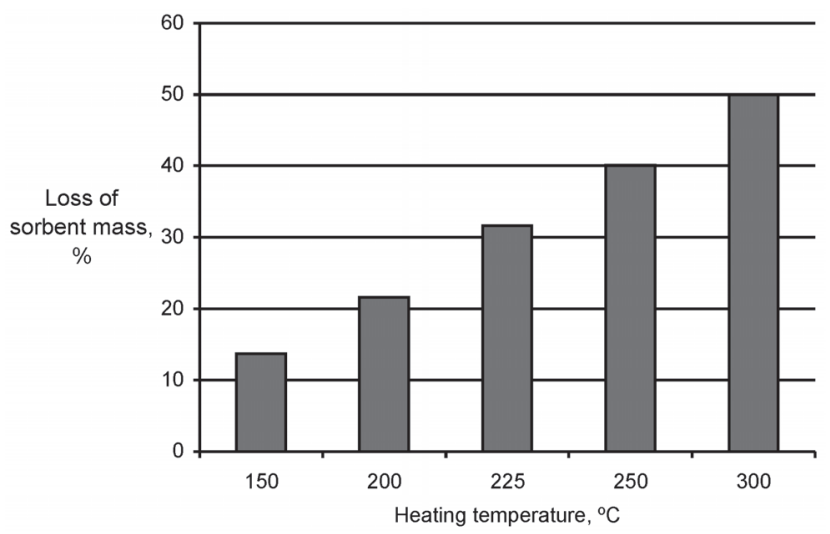

Fig 2. Biosorbent mass loss after $60 \mathrm{~min}$ of heating at different temperatures 


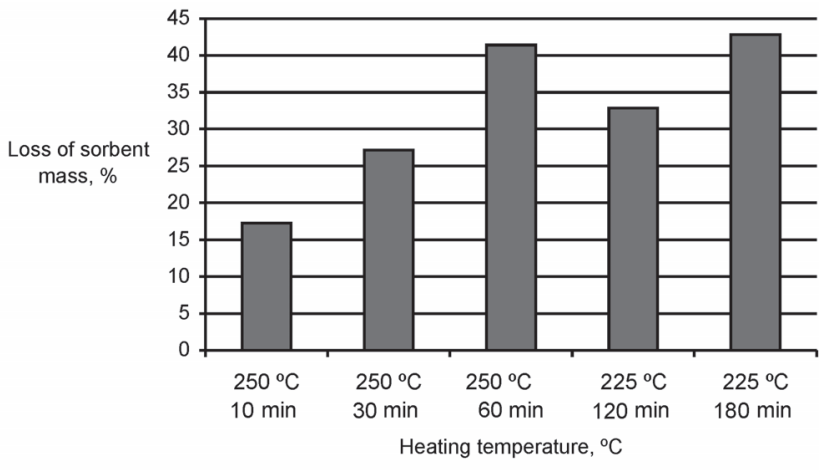

Fig 3. Loss of the biosorbent mass at a heating temperature of 225 and $250{ }^{\circ} \mathrm{C}$ with a different period of heating time

As it is seen in Fig 2, loss of the biosorbent mass is proportional to increase of temperature. The same trend is seen when increasing the heating duration (Fig 3).

The longer the heating duration, the higher the mass loss. After heating a biosorbent at different temperatures, water and oil product absorption was observed after 60 min of heating at different temperatures (Fig 4). Wa- ter soaking without heating is similar to that in the previous experiments [15].

As it is seen in Figs 4 and 5 increase of temperature results in a gradual decrease of water absorption to 2,31 1 of water/g of a biosorbent (at a heating temperature of $225^{\circ} \mathrm{C}$ ). At a heating temperature of $250{ }^{\circ} \mathrm{C}$ and higher water absorption starts increasing - 3,26 and 3,33 $\mathrm{g}$ of water/g of a biosorbent.

Such an increase in absorption is determined by the fact that charring of biosorbents starts at these temperatures. This results in disintegration of a porous structure of a sorbent, and it disintegrates into fine particles. Water fills the total outer surface of the sorbent, and particles, having no more pores, start sinking into water.

After each heating the spectrum of the biosorbent sample was analysed.

Analysing the data of IR spectrum analysis, chemical changes were noticed in the biosorbent structure. After systematizing the research data, graphs of IR spectrum analysis were made (Figs 6 and 7), where the intensity of IR rays passed through the sample in question expressed by the absorption coefficient is given on

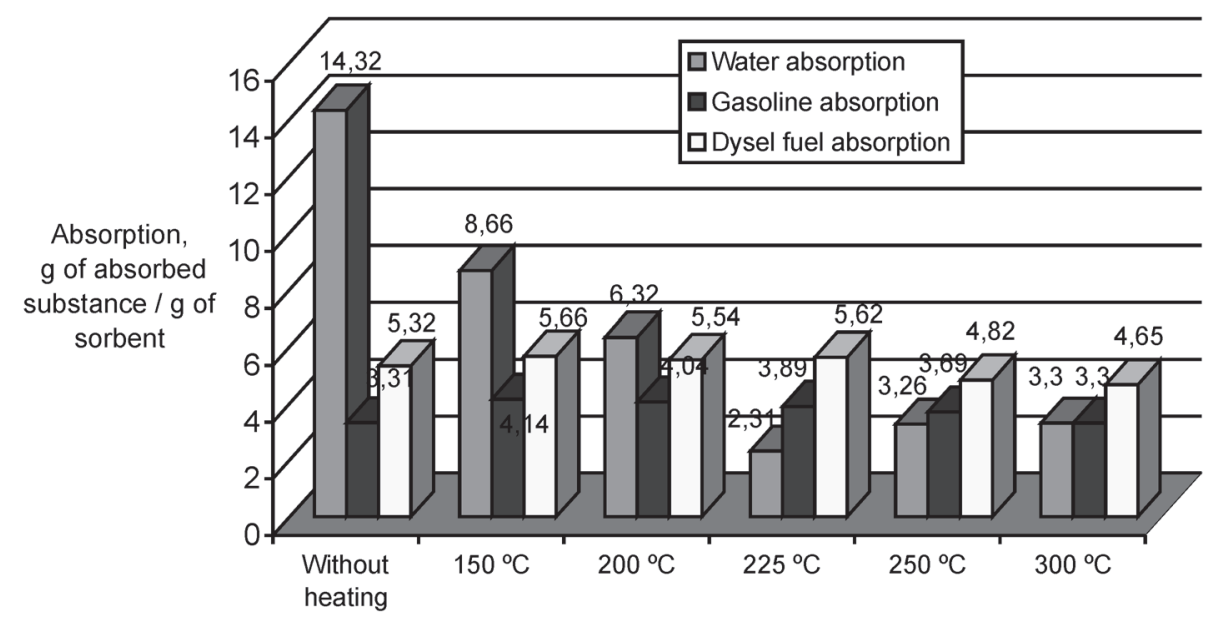

Fig 4. Absorption of water and oil products after 60 min of heating at different temperatures

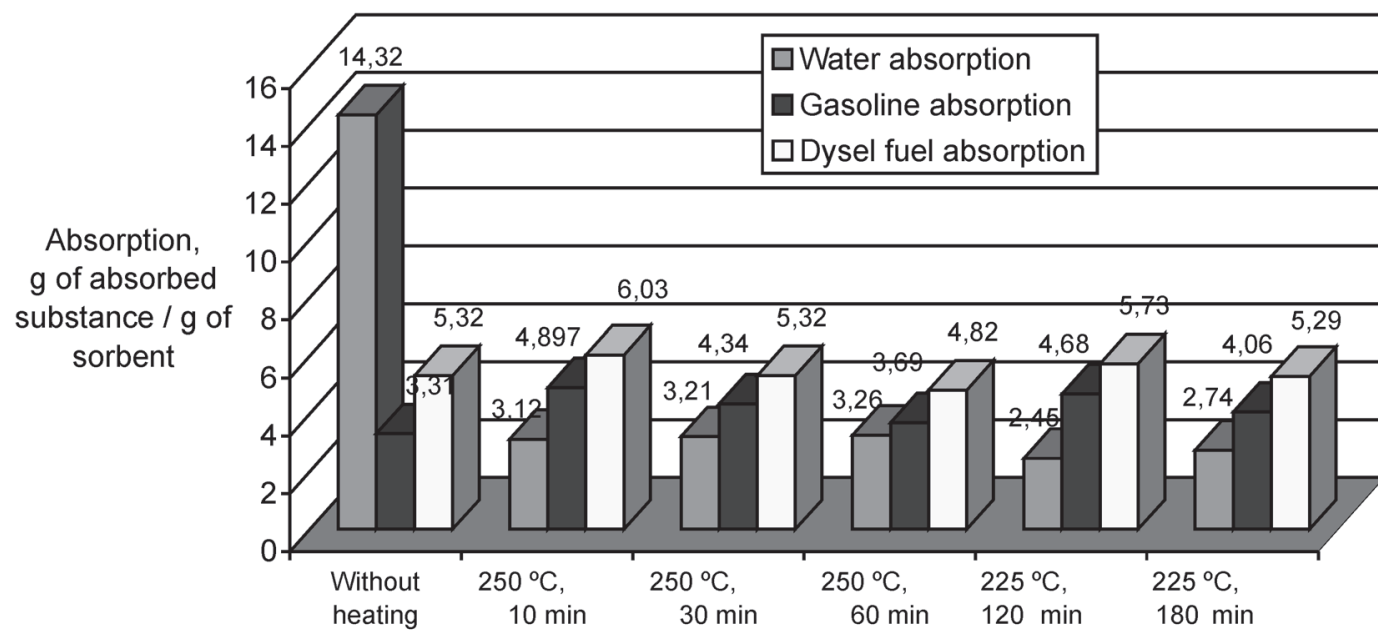

Fig 5. Absorption of water and oil products at heating temperatures of 225 and $250{ }^{\circ} \mathrm{C}$ 


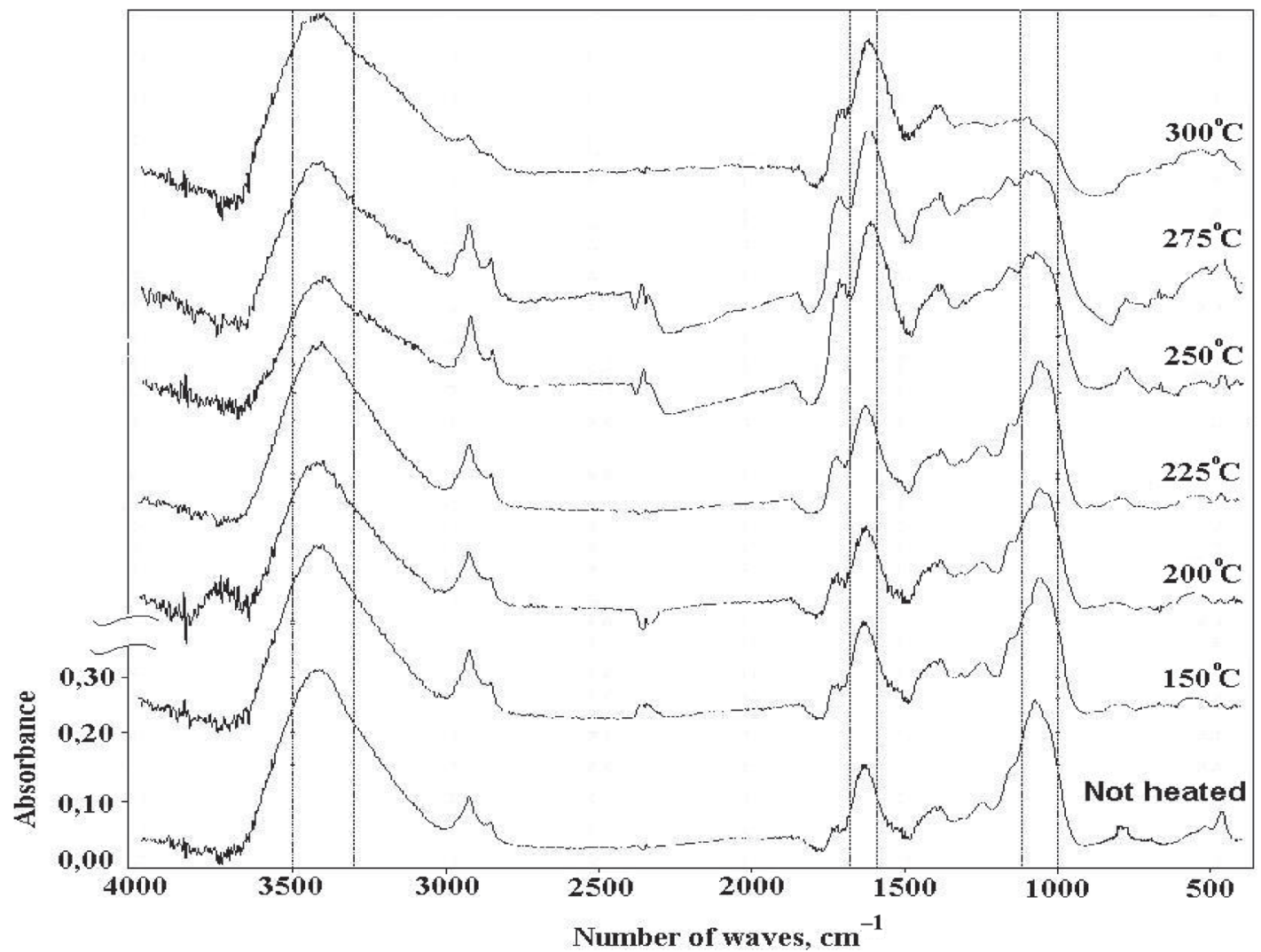

Fig 6. IR ray absorption spectrum at various heating temperatures for heating duration of $60 \mathrm{~min}$

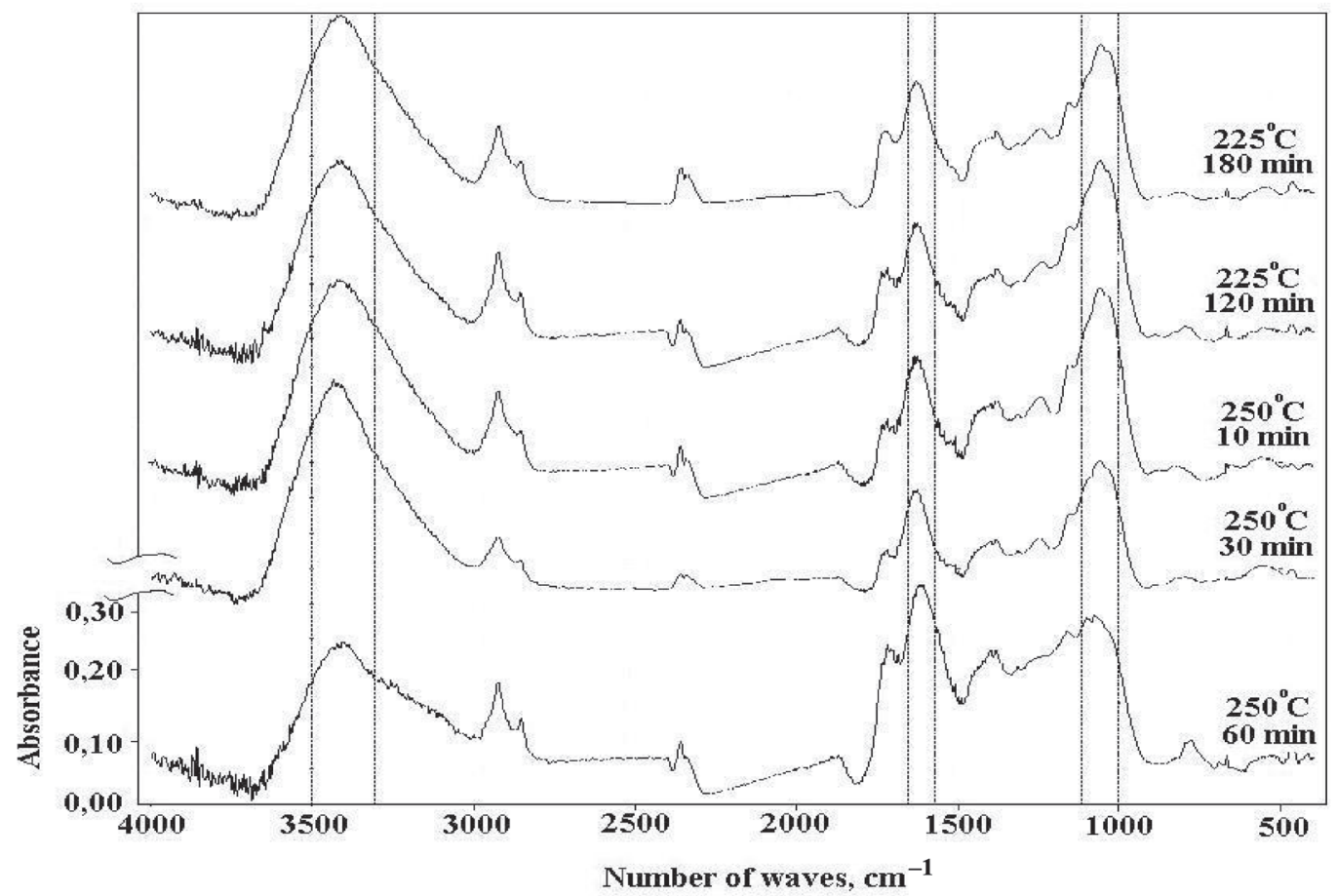

Fig 7. IR ray absorption spectrum at a heating temperature of 225 and $250{ }^{\circ} \mathrm{C}$ for a different heating duration 
the ordinate axle and the number of waves $\left(\mathrm{cm}^{-1}\right)$ is given on the abscissa. This dimension is used due to its direct proportionality to IR ray frequency, as the main attention is focused on the sphere of hydroxide absorption waves (wave numbers $3500-3300 \mathrm{~cm}^{-1}$ ) and on the sphere of absorption waves of carbon group (wave numbers $1740-1600 \mathrm{~cm}^{-1}$ ).

As it is seen in Fig 6, no major structural changes were noticed in the sphere of carbon group absorption waves (wave numbers $1740-1600 \mathrm{~cm}^{-1}$ ) at different biosorbent heating temperatures - the peak of absorption curves does not change. This could be explained by the absence of esters in the moss sorbent structure. Esters have the greatest influence on carbon combination breakage in the IR ray sphere. Disappearance of absorption waves at $3000 \mathrm{~cm}^{-1}$ wave number shows the disintegration of $\mathrm{C}-\mathrm{O}$ combination. This reveals the total charring of the biosorbent. The start of charring and disintegration $\mathrm{pf}$ hydroxide may be seen by observing disintegration of $\mathrm{C}-\mathrm{O}-\mathrm{H}$ combination at the wave numbers $1000-1050 \mathrm{~cm}^{-1}$. As seen in Fig 6, decrease in absorption waves is seen at a heating temperature of $250{ }^{\circ} \mathrm{C}$ which indicates the start of biosorbent charring. Charring of the biosorbent in thermal modification is unacceptable, as the structure of sorbent skeleton and pores disintegrate, and inflammation of the sorbent may occur. To have a more specific definition of a marginal heating temperature, extra heating of the biosorbent at $225^{\circ} \mathrm{C}$ for $180 \mathrm{~min}, 225^{\circ} \mathrm{C}$ for $120 \mathrm{~min}, 250{ }^{\circ} \mathrm{C}$ for 10 min and $250{ }^{\circ} \mathrm{C}$ for 30 min was performed. IR absorption wave graphs in Fig 7 show that when the biosorbent is heated at $225{ }^{\circ} \mathrm{C}$, disintegration of $\mathrm{C}-\mathrm{O}$ combinations is not noticed (wave numbers $1000-1050 \mathrm{~cm}^{-1}$ ). After 10 min of heating the absorbent at $250^{\circ} \mathrm{C}$, a decrease in the number of absorption waves was noticed (wave number $1000-1050 \mathrm{~cm}^{-1}$ ). This means the beginning of disintegration of $\mathrm{C}-\mathrm{O}$ combinations. Thus, $250{ }^{\circ} \mathrm{C}$ is a critical temperature when performing thermal modification.

\section{Conclusions}

1.It is established that thermal modification of a biosorbent enables reduction of water absorption from 14,32 to $2,31 \mathrm{~g}$ of water / $\mathrm{g}$ of a biosorbent.

$2.225{ }^{\circ} \mathrm{C}$ is an optimal temperature for thermal modification. Heating duration is $60 \mathrm{~min}$. Increase in heating duration has a negative influence on water absorption which increases a little from 2,31 to $2,45 \mathrm{~g}$ of water / $\mathrm{g}$ of a biosorbent when heated for $120 \mathrm{~min}$, and to 2,74 when heated for $180 \mathrm{~min}$. This trend is affected by charring of fine particles of a biosorbent.

$3.250^{\circ} \mathrm{C}$ is a critical temperature for thermal modification of a biosorbent, as at this temperature disintegration of carbon combinations and charring of a biosorbent start.

4. Thermal modification enables decrease in water permeability but has a negative influence on oil product permeability on a water surface. Oil product absorption decreases with increasing heating temperature. But the effect of water absorption decrease is much higher.

5. At an optimal heating temperature with regard to water absorption $\left(225^{\circ} \mathrm{C}\right)$ petrol absorption is $3,89 \mathrm{~g}$ of oil products/g of a biosorbent, that of diesel fuel $-5,62 \mathrm{~g}$. At a heating temperature of $150{ }^{\circ} \mathrm{C}$ petrol absorption is $4,14 \mathrm{~g}$ of oil products $/ \mathrm{g}$ of a biosorbent, that of diesel fuel $-5,66 \mathrm{~g}$. Thus, decrease in oil product absorption was insignificant, while water absorption went down from 8,66 to $2,31 \mathrm{~g}$ of water/g of a biosorbent. Decrease in oil product absorption is lower, compared to decrease of water absorption. Thus, the effect of thermal modification is obvious.

\section{References}

1. Soil wash technologies. 215 North Marengo Avenue, Suite 10, Pasadena, USA, 1999. 25 p.

2. Grigiškis, S.; Žunda, G.; Čipinytè, V. Užteršto grunto valymo technologijos. Statyba ir architektūra. 99/10. 1999, p 24-28.

3. Selection Criteria and Laboratory Evaluation of Oil Spill Sorbents. Update IV: 1991 Canada. 80 p.

4. Baltrènas, P.; Paliulis, D.; Vaišis V. Investigation of oil spill biosorbent SPHAG-SORB. Environmental Engineering. Vol X, No 3. Vilnius: Technika, 2002, p 103-107 (in Lithuanian).

5. Tilkanen, J.; Rytkönen, J. \& Liukkonen, S. Absorbent Tests and the Re-Use of Sorbtion Materials. VTT Seminar on Biotechnology for Marine Oil Spills and Contaminated Soils in Cold Climate, Espoo, 1995. 12 p.

6. Chiras, D. D. Environmental science: Action for a sustainable future. California, 1991, p 539-548.

7. Choi, H.; and Cloud, R. M. Natural Sorbents in Oil Spill Cleanup. Environmental Science and Technology, Vol 26, No 4 April 1992, p 772-776.

8. Hills, W. E. Hight temperature and chemical effects on wood stability. Part 1: General considerations. Wood Sci. Technology, 18, p 281-293.

9. Ghalambor, A. Evaluation and Characterization of Biodegradable Sorbents. Lousiana Oil Spill Coordinators Office. Technical report Series 006, 1998. 32 p.

10. Čipinyte, V. Biological cleaning of soil polluted by oil products. Kaunas, 2000. 97 p (in Lithuanian).

11. Abraham, S. Evaluation and Characterization of Sorbents for Oil Spill Removal. M.S. Thesis, University of Southwestern Louisiana, 1995. $193 \mathrm{p}$.

12. Cooper, D., and Gausemel I. Oil Spill Sorbents: Testing Protocol and Certification Listing Program. Oil Spill Conference: Prevention, Preparedness, Response, Tampa, FL., 29 March 1993. 553 p.

13. Schrader, E. L. A Practical Composition of Organic, Synthetic and Inorganic Sorbents. Paper Presented at the Clean Gulf 93 and the American Chemical Society Conference: Emerging Technology in Hazardous Waste Management, 1993, 17 p.

14. Bragg, J. R.; Prince, R.C.; Wilkinson, J. B. \& Atlas, R. M. Bioremediation for Shoreline Cleanup Following the 
1989 Alaskan Oil Spill. Exxon Research and Engineering Company, 1992. 94 p.

15. Baltrènas, P; Paliulis, D; Vaišis, V. Investigation of
Biosorbents for Oil Products and Their Use Advantages. Environmental Engineering and Landscape Management, 2003, Vol XI, No 2, p 47-53.

\section{EKSPERIMENTINIAI TERMINĖS MODIFIKACIJOS İTAKOS BIOSORBENTO SORBCINĖMS SAVYBE்MS TYRIMAI}

\section{P. Baltrẻnas, V. Vaišis}

\section{S a n tra u a}

Surenkant naftos produktus nuo vandens paviršiaus neišvengiama vandens igerties. Sorbentas ima skęsti vandenyje bei prasteja jo talpumas naftos produktams. Ankstesni eksperimentiniai tyrimai parodė [15], jog biosorbentas iš Lietuvoje augančių samanu kiminų efektyviai sorbuoja naftos produktus nuo vandens paviršiaus, tačiau didelè yra ir jo vandens igertis $(14 \mathrm{~g}$ vandens/g biosorbento). Siekiant sumažinti vandens igeriamumą, biosorbentą būtina impregnuoti ar kitaip modifikuoti. Impregnuojant sorbente atsiranda cheminių medžiagų, kurios, likus sorbentui gamtoje, didina taršą. Vienas iš perspektyviausių modifikavimo būdų nenaudojant papildomų cheminių medžiagų yra terminis modifikavimas. Kaitinant biosorbente i̇vyksta cheminių pakitimų $(-\mathrm{COOH}$ bei $-\mathrm{OH}$ laisvujų radikalų skilimas). Tai turi ịtakos vandens molekulių prisijungimui. Sumažejus šių laisvujų radikalų mažèja vandens igeriamumas. Biosorbentas iš samanų kiminų yra labai degus, todèl technologiškai svarbu nustatyti pakankamą ir saugią kaitinimo temperatūrą bei kaitinimo trukmę.

Raktažodžiai: naftos produktų išsiliejimai, terminis modifikavimas, optimali kaitinimo temperatūra.

\section{ЭКСПЕРИМЕНТАЛЬНЫЕ ИССЛЕДОВАНИЯ ВЛИЯНИЯ ТЕРМИЧЕСКОЙ МОДИФИКАЦИИ НА СОРБЦИОННЫЕ СВОЙСТВА БИОСОРБЕНТА}

\section{П. Балтренас, В. Вайшис}

Р е $з$ ю м е

При сборе нефтепродуктов с поверхности воды трудно избежать впитываемости воды. Это отрицательно влияет на впитываемость нефтепродуктов и приводит к погружению сорбента. Эксперименты показали [15], что биосорбент из местного торфяного мха эффективно сорбирует нефтепродукты с поверхности воды. Однако и впитываемость воды также велика (14 г воды / г биосорбента). С целью уменьшить впитываемость воды необходимо биосорбент импрегнировать или иначе модифицировать.

При импрегнации применяются химикалы, которые могут отрицательно влиять на окружающую среду при неполном сборе сорбента. Одним из перспективных методов модификации без введения химикалов является термическая модификация. При нагревании в биосорбенте разлагаются $-\mathrm{COOH}$ и $-\mathrm{OH}$. Это оказывает воздействие на присоединение молекул воды. С уменьшением числа свободных радикалов уменьшается водопоглощение. Биосорбент из торфяного мха легко воспламеняется, поэтому очень важно, чтобы температура была достаточной и безопасной.

Ключевые слова: загрязнение нефтепродуктами, термическая модификация, оптимальная температура.

Pranas BALTRÉNAS. Dr Habil, Prof and head of Dept of Environmental Protection, Vilnius Gediminas Technical University (VGTU), Sauletekio al. 11, LT-10223 Vilnius-40, Lithuania. E-mail: aak@ap.vtu.lt

Doctor Habil of Science (air pollution), Leningrad Civil Engineering Institute (Russia), 1989. Doctor of Science (air pollution), Ivanov Textile Institute (Russia), 1975. Employment: Professor (1990), Associate Professor (1985), senior lecturer (1975), Vilnius Civil Engineering Institute (VISI, now VGTU). Publications: author of 13 monographs, 24 study-guides, over 320 scientific papers and 67 inventions. Honorary awards and membership: prize-winner of the Republic of Lithuania (1994), a corresponding Member of the Ukrainian Academy of Technological Cybernetics, a full Member of International Academy of Ecology and Human Protection. Probation in Germany and Finland. Research interests: air pollution, pollutant properties, pollution control equipment and methods

Vaidotas VAIŠIS. MSc, doctoral student, Dept of Environmental Protection, Vilnius Gediminas Technical University (VGTU), Saulètekio al. 11, LT-10223 Vilnius-40, Lithuania. E-mail: vaisisv@ap.vtu.lt

Master of Science (environmental protection engineering), VGTU, 2001. Bachelor of Science (environmental engineering), VGTU, 1999. Publications: author of 8 scientific publications. Research interests: environmental protection, pollution prevention. 